\title{
Abnormal Returns and Fundamental Analysis in Institutional Investors' Decision-making: An Agency Theory Approach
}

\author{
Mario Mustilli ${ }^{1}$, Francesco Campanella ${ }^{1}$, Eugenio D’Angelo ${ }^{2}$ \\ ${ }^{1}$ Department of Economics, University of Campania “Luigi Vanvitelli”, Capua, Italy \\ ${ }^{2}$ Department of Economics and Legal Studies, Pegaso Telematic University, Naples, Italy \\ Correspondence: Eugenio D'Angelo, Department of Economics and Legal Studies, Pegaso Telematic University, \\ Naples, Italy.
}

Received: December 18, 2017

Accepted: January 5, 2018

Online Published: January 8, 2018

doi:10.5539/ibr.v11n2p55

URL: https://doi.org/10.5539/ibr.v11n2p55

\begin{abstract}
The purpose of this paper is to investigate the abnormal returns achieved by institutional investors. Distinguishing between institutional investors operating with a specific mandate to invest and those that operate their own choices independently from such a specific delegation, we show that the former achieve higher abnormal returns than the latter. The conceptual explanation of this result is attributable to the use of the fundamental analysis that the first type of institutional investors realized in a higher and more effective way than the second. This different approach in selecting securities might be due to the relationship between the institutional investor and the savers who provided capital. This different agency relationship might have been reflected in the institutional investor's investment policies through the agent behaviour, which changes depending on the nature of the principal who has given the mandate. The empirical analysis has been conducted on a sample of 5,500 institutional investors operating all around the world in 2014, drawing data from institutional investor's annual report, from their investment relations and from Bloomberg, Thomson Reuters, Bankscope, Eurostat and through Computer Assisted Telephone Interviews.
\end{abstract}

Keywords: agency theory, institutional investors, fundamental analysis, abnormal return

\section{Introduction}

Contractual relations are the heart of all economic activities. Contracts have indeed been the centre of many theoretical analyses since the time of Adam Smith. The reason why the contract is an important tool for understanding economic phenomena, is related to the greater or lesser capacity to regulate relations between subjects who might have different interests and, at the same time, act in a more or less direct and cooperative relationship (Hart, Holmstrom, 2016).

The way in which the behaviour of contractors are brought in to balance will depend on how these contracts, more or less complete or explicit, will be able to regulate the way in which remuneration and risks, arising from property rights, will be allocated among the parts that are normally characterized by divergent interests (Coase, 1937, 1960; Alchian, 1965; Alchian and Kessel, 1962; Demsetz, 1967; Alchian and Demsetz, 1972; Monsen and Downs, 1965; Silver and Auster, 1969; McManus, 1975).

Jensen and Meckling (1976), studying the capital structure, analyzed the behavioural implication of property rights in the contracts. Scholars, questioning about optimal composition of funding sources, defined the agency relationship as a contract by which one or more parties, defined principal, engage another person, called agent, to carry out some work in their interest, involving the reassignment of some authority in terms of decision-making autonomy. Authors state that, in this type of contract, if both parties tend to maximize their own utility function, there are good reasons to believe that the agent does not always behave in the best interests for the principal. For this reason, agency costs may arise and authors lead back them to three categories: monitoring expenditure by the principal, bonding expenditures by the agent and residual loss.

What let arise agency costs is therefore, essentially, the uncertainty, the resulting condition of information asymmetry, actual or perceived, and the attempt to reduce it (Campanella et al., 2013). The principal suffers the uncertainty related to the actions and decisions taken by the agent and the agent suffers the uncertainty regarding the results of his actions. The contracts will be made more complex in order to reduce information asymmetry 
and uncertainty that generate the known opportunistic behaviour such as adverse selection and moral hazard.

As claimed by Jensen and Meckling, agency relationships do not occur only at company level but in all relationships that involve cooperative efforts (public offices, governments, cooperatives, etc.).

In addition, the agency relationships are identifiable not only in the simple principal-agent relationship, typical of the relation between a single owner and the manager, but also in cases of widespread ownership.

In addition, the arising of agency costs for the shareholder would not eliminated even in the case in which the firm is partially financed by debt capital.

Even if in this case there are some advantages in terms of control, because of the need to inform the lender of capital about company's capacity to ensure the debt service, there are several possible types of disadvantages for the principal. The indebted company is exposed, in addition to the bonding cost and to the costs of increased reporting, to the risk of bankruptcy. To avoid this risk, and at the same time to safeguard its role in the enterprise, the manager may choose less risky investment projects that ensure the company's survival, reducing the return on equity. On the other hand the cost of capital for an indebted company will be lower than in the case of a company financed only with equity, given that the cost of debt reduces the weighted average cost of capital. Therefore, in such a financial structure, the pressure on higher performance, given by the financial structure, which is ine vitably linked to the risk of investment projects, will be less strong than in cases where the company is financed exclusively through equity.

For all these reasons it appears evident that the capital structure will affect in some way the managerial behaviour and, consequently, firm's performance.

A large number of studies on capital structure, having as their object the relationship between corporate governance and financial performances, has shown that the presence of an institutional investor, as an equity holder, is associated with better performance because monitoring by this kind of principal is an important governance mechanism. As noted by Almazan et al. (2004), theory and empirical evidence suggest that active monitoring capabilities are difficult for smaller or less- informed investors (Kaplan and Minton, 1994; Kahn and Winton, 1998; Del Guercio and Hawkins, 1999; Gillan and Starks, 2000; Almazan and Suarez, 2003). Monitoring activities, therefore, is reflected, also and above all, in the fundamental analysis performed by institutional investors in selecting their portfolios and that leads them to realize greater abnormal returns (Campanella, Mustilli, D'Angelo, 2016).

This paper investigates the abnormal returns achieved by institutional investors, distinguishing them according to the more or less specific mandated to invest that has been received by savers who provided them the capital. Therefore we argue that the type of agency relationship explains the more effective use of fundamental analysis and therefore the abnormal return achieved by institutional investors.

The paper falls into four further sections. The first section contains the theoretical framework and the research hypotheses of the study. The second section is dedicated to the methodology and to the description of sample and variables. The third section shows the results of the study and the last section is dedicated to the discussion and to conclusions.

\section{Theoretical Framework and Research Hypothesis}

According to the Italian Stocks Exchange definition, institutional investors are classified as follows: collective investment companies, investment funds (real estate, stocks and hedge funds), pension funds and insurance companies.

The investing activity carried out by such institutional investors can derive from an explicit mandate given by savers, therefore the investment is done on a collective basis, as in mutual funds, or may be disjoined from the saver's invested capital, as in the case of insurance companies. Therefore, for the purposes of our research, it is possible to identify two distinct categories of institutional investors:

1) Institutional investors whose activity is derived from an explicit and detailed contract, so the investment is made on a collective basis, as in mutual funds. In this case the mandate comes from savers who are fully aware of the market risk derived from the investment activity made by the fund. The willingness of the saver is to invest in the financial market and the mandate details the investment strategies that will be used by the fund. In this case savers delegate the professional institutional investor to carry out an investment activity on their behalf. Institutional investors who fall into this category are following named "Banks".

2) Institutional investors whose investing activity is not linked to a specific mandate given by the savers, as in the case of insurance companies. In this case, the institutional investor operates without a specific mandate, with 
a greater freedom in choosing their investment strategies. Institutional investors who fall into this category are following named "Insurance Companies".

Essentially, moving from the position of the saver, we will have two possible solutions: indirect investment through a vehicle (Banks) or direct investment (insurance companies), as shown in the example described in the figure 1

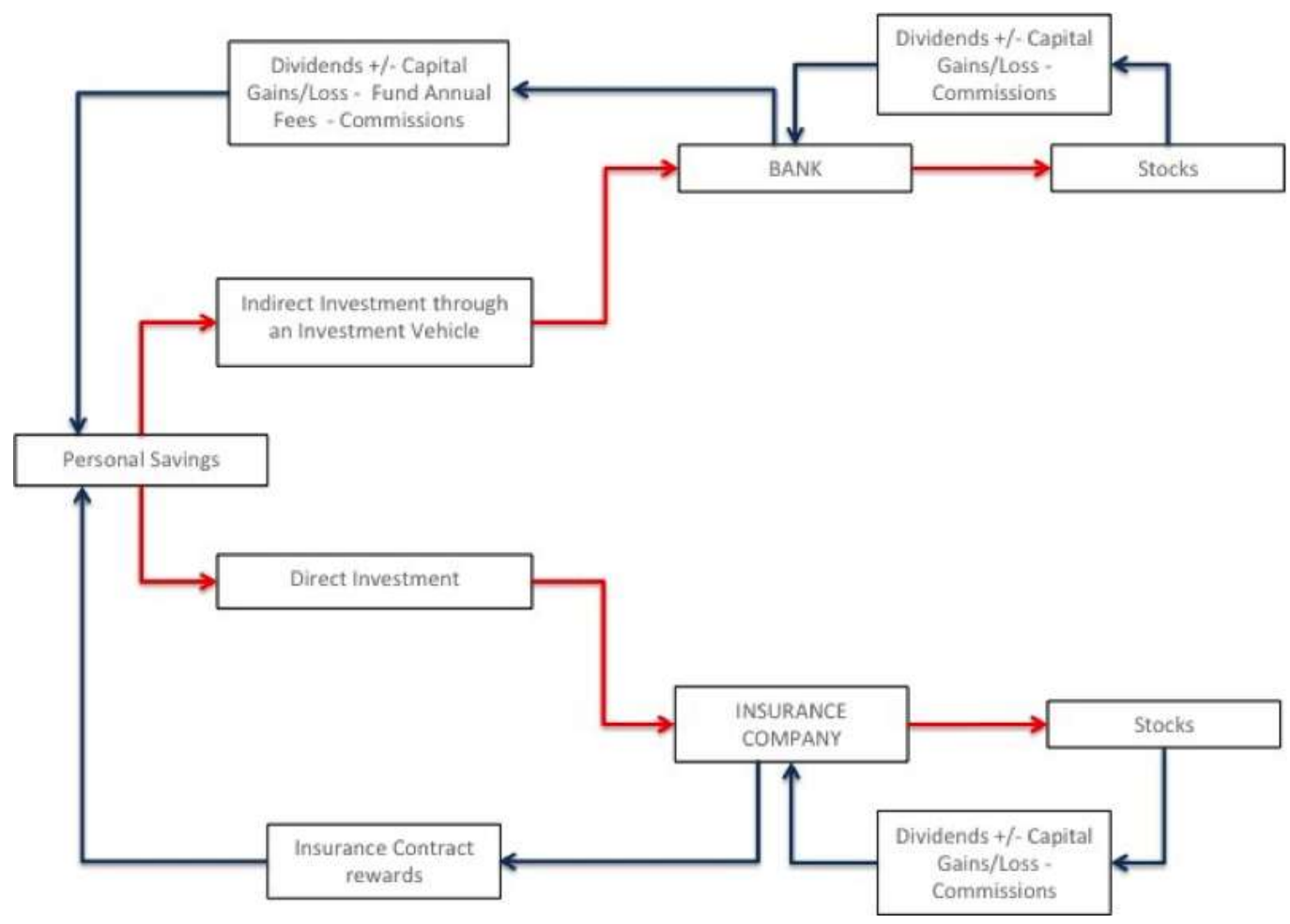

Figure 1. The flow of capital and rewards in the case of specific mandate or non-specific mandate

In the first case (Bank), money flows directly into an investment vehicle that employs it in the purchase of stocks. The compensation provided by the investment made by the vehicle, typically dividends and capital gains, net commissions paid for purchasing operations and any capital losses, will coincide with the return of the investor, net fund's management fee that will be held periodically by the fund.

In the other case, the saver will sign a contract with the Insurance Company and its remuneration is essentially described in the contract. Money given by the savers to the Insurance Company will be, in the end, partly invested in shares, but this time the remuneration arising from such purchase of shares will be only a prerogative of the Insurance Company that has invested and not any more given to the personal saver.

Therefore, in both cases, the money provided by the savers may be finally invested in a portfolio of shares, but, in the case of Bank, saver's reward is tied to the investment in shares, while, in the second case, the one of the Insurance Company, the remuneration taken by the saver will be linked to another contract and therefore will be independent from the share's equity return on investment.

From a theoretical point of view, the difference between the two cases taken into consideration is mainly connected to the different type of multiple agency relationships that arises along the investment chain. These differences will push the Bank, unlike the Insurance Company, to adopt fundamental analysis in their portfolio selection and, thanks to this approach, to achieve higher abnormal returns. This condition will guarantee both a higher return in terms of fees and a higher reputation for the institutional investor.

Two different positions may arise according to agency theory. In the case of Banks, the position of the saver who gave money to the institutional investor, with a binding mandate to invest in shares, is equivalent to the one of a minority principal, while in the case of Insurance Companies, the position of the saver that gave money to the institutional investor is equivalent to the one of a debt holder.

The next step of the investing flow chain regards the contractual relationship between Bank and Insurance in relation to the targeted company. The institutional investor positions, that we have defined Insurance on one hand and Bank on the other, in this case are rather similar. For both solutions, a typical position of principal-agent 
relationship may arise.

Therefore, in order to demonstrate our theoretical framework, it is not necessary to concentrate on the agency relationship that binds the second part of the investment chain (principal-agent), in other words the one through which Bank and Insurance Company are linked to targeted company, but to the first relationship, which links the saver and the institutional investor that invests in target (figure 2).

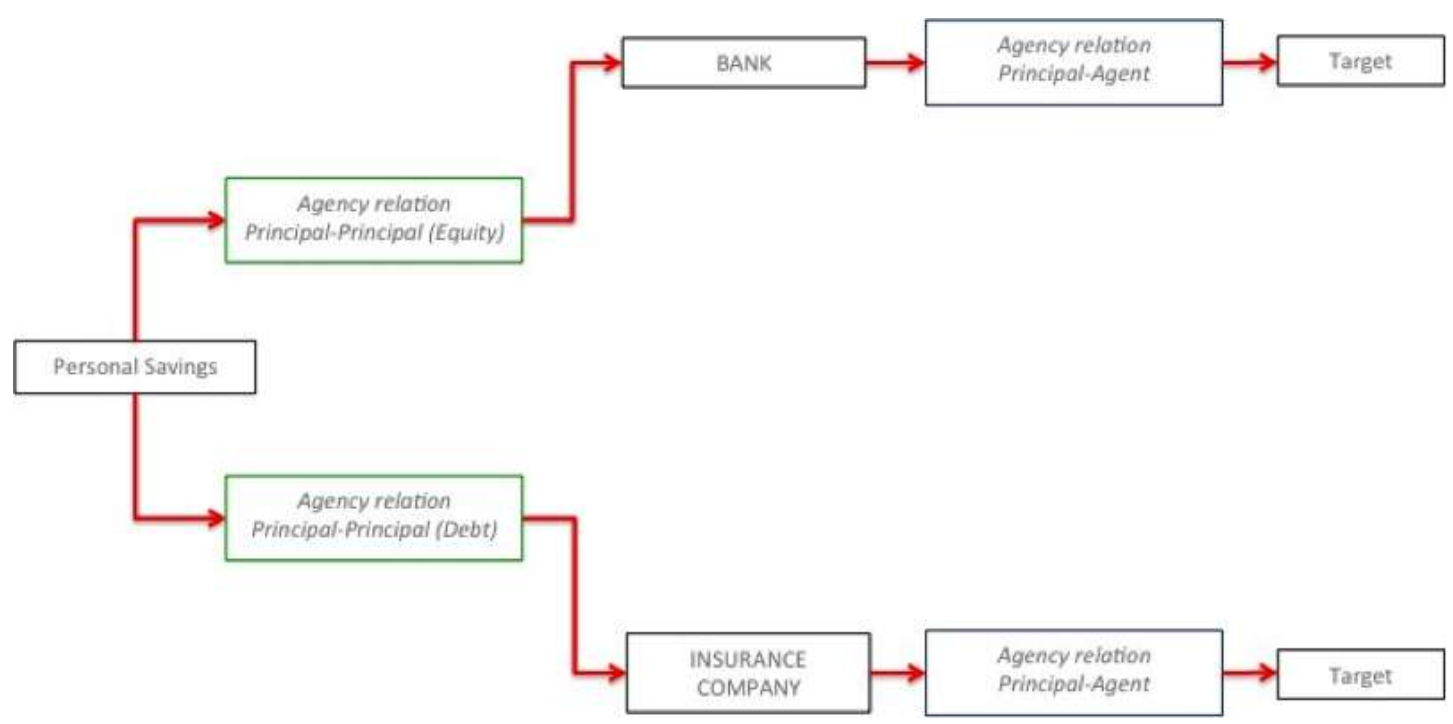

Figure 2. Agency relationships in the investing chain

If the relationship between the saver and the institutional investors were the same, there will be no different results in terms of abnormal returns gained by the target stocks, since there would be no difference in the way in which the management of Bank and Insurance Company would elaborate their investment policies. Conversely, since the capital structure is different, this may result in influencing the management of the two type of institutional investors when it comes to their portfolio selection.

More in detail, the agency relationship associated with debt (Insurance Companies) leads to a higher cost of monitoring held by the investment company. In this condition, the investor will face, on one hand, the monitoring costs for the equity holders and, on the other, will incur into bonding costs.

It is clear that a capital structure that includes a financial debt (which is guaranteed by an insurance benefit) will have a weighted average cost of capital lower than in the case of an investor exclusively financed by an equity holder. The risk of bankruptcy will also lead the institutional investor to select stocks characterized by a lower risk-return trade off. The costs arising from the additional monitoring arising from debt, will have the effect of consuming cash flows that otherwise would be used to run a highly cost consuming fundamental analysis on target stocks. Conversely, the principal-principal relationship, typical of the relationship between savers and Bank, pushes the latter, characterized by a higher cost of capital, lower agency costs and the absence of the bankruptcy risk, to use fundamental analysis in the composition of its securities portfolio, taking higher risks in terms of risk-return trade off and thus to outperform in terms abnormal returns.

This leads us to the following hypotheses:

H1: Institutional investors with a specific mandate of investors (Banks) show abnormal returns higher than the other (Insurance Companies).

$\mathrm{H} 2$ : Institutional investors with a specific mandate of investors (Banks) use fundamental analysis in formulating their investments strategies.

\section{Materials and Method}

The sample used in this research is made of 5,500 institutional investors located all over the world and is composed of 2.645 institutional investors named as "banks" and 2.855 institutional investors named "Insurance Companies" as described in section number one of the paper.

To verify the research hypotheses, we employed the classification analysis method. The classification rule for a research sample has to be defined before building the classification tree (Andone and Sireteanu, 2009). The 
classification rule for this research is to make the distinction between "Banks" and "Insurance Companies". This classification rule is reflected in the $\mathrm{Y}$ variable for the classification tree. Variable $\mathrm{Y}$ has been structured as follows:

$\mathrm{Y}=$ is a dummy variable which assumes value 0 or 1 depending if the institutional investor is a "Insurance Company" or a "bank".

At this point, a recursive partition technique was applied to assign each statistical unit to one of the classes defined a priori by Y. The sample units were repeatedly split into groups, which were increasingly more homogeneous with respect to the dependent variable $\mathrm{Y}$. The splitting procedure was conducted with reference to the explanatory variables $\mathrm{X}=\left(\mathrm{X}_{1}, \mathrm{X}_{2}, \ldots, \mathrm{X}_{\mathrm{s}}, \ldots, \mathrm{X}_{\mathrm{p}}\right)$.

In line with the aim of their research, the authors had to define the variables (X) that have a bearing on "Bank" and "Insurance".

Accordingly, we defined the following independent variables:

- $\quad$ Abnormal returns $_{\mathrm{t}}=\mathrm{r}-\mathrm{E}(\mathrm{r})$; where: $\mathrm{r}=$ portfolio return at time $\mathrm{t} ; \mathrm{E}(\mathrm{r})=$ portfolio expected return at time $\mathrm{t}-1$. The abnormal return has been measured through the difference between the portfolio's effective return and the expected return measured using the "market model". The effective return has been measured as follows: $r=\log$ $\left(\mathrm{P}_{t} / \mathrm{P}_{\mathrm{t}-1}\right)$ where: $\mathrm{P}_{\mathrm{t}}=$ price of the security at time of dividend announcement; $\mathrm{P}_{\mathrm{t}-1}=$ price of the security at time $\mathrm{t}-1$.

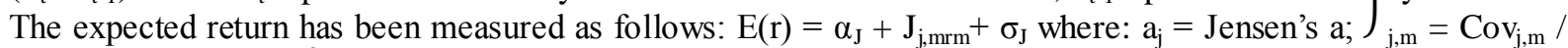
$\operatorname{Var}_{\mathrm{m}}=\left(\mathrm{o}_{\mathrm{j}} \mathrm{o}_{\mathrm{m}} \mathrm{q}_{\mathrm{j}, \mathrm{m}}\right) / \mathrm{o}_{\mathrm{m}}{ }^{2} ; \mathrm{r}_{\mathrm{m}}=$ daily index of the reference market. The variable takes value 1 if $\quad \mathrm{r}-\mathrm{E}(\mathrm{r})>0$ and 0 otherwise.

- $\quad\left(\mathrm{D}_{\mathrm{t}-1} / \mathrm{E}_{\mathrm{t}-1}\right)=\left(\right.$ Book value of the indebtedness $\mathrm{t}_{\mathrm{t}-1} /$ Book value of equity $\left.\mathrm{t}_{\mathrm{t}-1}\right)$. This variable reflects the leverage of the firm concerned and is a proxy of the financial risk. This variable takes the value 1 if the institutional investor has used a high level of this variable as choosing criteria for the targeted company.

- $\quad \mathrm{EPS}_{\mathrm{t}-1}=$ earnings per share at $(\mathrm{t}-1)=\left(\right.$ After-tax profit $_{\mathrm{t}-1} /$ Number of shares $\left.\mathrm{s}_{\mathrm{t}-1}\right)$. This variable reflects the profit that was distributed to the shareholders in the form of dividends and capital gains for each share held by each of them. This variable takes the value 1 if the institutional investor has used a high level of this variable as choosing criteria for the targeted company.

- $\quad \mathrm{ROE}_{\mathrm{t}-1}=$ Return on equity $(\mathrm{t}-1)=\left(\right.$ After-tax profit $\mathrm{t}_{-1} /$ Equity $\left._{\mathrm{t}-1}\right)$. This variable reflects the book value of the returns accruing to shareholders. This variable takes the value 1 if the institutional investor has used a high le vel of this variable as choosing criteria for the targeted company.

- Current ratio t $-1=\left(\right.$ Current assets $_{\mathrm{t}-1} /$ Current $\left._{\text {liabilities }} \mathrm{C}_{\mathrm{t}-1}\right)$. This variable indicates whether the amount of the assets that will be recovered in cash within the year exceeds the amount of the debt to be repaid over the same period of time. This variable takes the value 1 if the institutional investor has used a high le vel of this variable as choosing criteria for the targeted company.

$\left(\mathrm{NFP}_{\mathrm{t}-1} /\right.$ Total $\left._{\text {assets }} \mathrm{t}_{\mathrm{t}-1}\right)=\left(\right.$ Net financial position $\mathrm{t}_{\mathrm{t}-1} /$ Total book value of assets $\left.\mathrm{t}_{\mathrm{t}-1}\right)$. This variable indicates the proportion of the company's investments that was financed with borrowed funds and, hence, illustrates the composition of its sources of funds. The net financial position is defined as debt minus liquid assets. This variable takes the value 1 if the institutional investor has used a high le vel of this variable as choosing criteria for the targeted company.

$\left(\right.$ EBIT $_{t-1} /$ Financial expenses $\left.s_{t-1}\right)=\left(\right.$ Earnings before interests and taxes $t_{t-1} /$ Financial expenses $\left.t_{t-1}\right)$. This variable reflects the part of the costs of its financial resources that the firm is able to finance out of its own earnings before interest and taxes. This variable takes the value 1 if the institutional investor has used a high level of this variable as choosing criteria for the targeted company.

- $\quad\left(\mathrm{P}_{\mathrm{t}-1} / \mathrm{E}_{\mathrm{t}-1}\right)=\left(\right.$ Market cap $_{\mathrm{t}-1} /$ Net earnings $\left._{\mathrm{t}-1}\right)$. This variable measures the number of years over which the monetary value of the price is recovered if the security concerned generates a theoretically perpetual flow of annual net earnings of the level postulated at the time of the measurement. This variable takes the value 1 if the institutional investor has used a high level of this variable as choosing criteria for the targeted company.

- $\quad\left(\mathrm{P}_{\mathrm{t}-1} / \mathrm{Cash}_{\text {flow }} \mathrm{t}\right)=\left(\right.$ Market cap $\left._{\mathrm{t}-1} / \mathrm{Cash} \mathrm{flow}_{\mathrm{t}-1}\right)$. This variable measures the number of years over which the monetary value of the price is recovered if the security concerned generates a theoretically perpetual cash flow. This multiple can effectively help solve the greatest shortcoming of the P/E ratio, i.e. the fact that the net earnings of a company are dependent on its budget policies. This variable takes the value 1 if the institutional investor has used a high level of this variable as choosing criteria for the targeted company.

- $\quad\left(\mathrm{P}_{\mathrm{t}-1} /\right.$ Sales $\left._{\mathrm{t}-1}\right)=\left(\right.$ Market cap $_{\mathrm{t}-1} /$ Sales $\left._{\mathrm{t}-1}\right)$. This variable measures the number of years over which the value 
of the price is recovered if the security concerned generates a theoretically perpetual cash flow. It is especially useful to evaluate the performance of start-ups, since these are firms that due to substantial front-end investments tend to operate at a loss. Considering that it would hardly make sense to determine their P/E ratios and the fact that the primary aim of a firm is to boost its sales, it is interesting to establish what chances the market is prepared to take on their prospective sales potential. This variable takes the value 1 if the institutional investor has used a high level of this variable as choosing criteria for the targeted company.

- $\quad\left(\mathrm{P}_{\mathrm{t}-1} / \mathrm{BV}_{\mathrm{t}-1}\right)=\left(\right.$ Market cap $_{\mathrm{t}-1} /$ Book Value $\left._{\mathrm{t}-1}\right)$. This variable indicates the ratio between the market value of equity and the book value of it. This variable takes the value 1 if the institutional investor has used a high level of this variable as choosing criteria for the targeted company.

- $\quad$ Size Effect ${ }_{-1}=$ A variable which measures the sizes of the firms and is equal to the book value of the firm's total assets. This variable takes the value 1 if has been used by the institutional investor as choosing criteria for the targeted company.

- $\quad$ Industry = A variable which measures the industry in which the firms conducts the business. This variable takes the value 1 if has been used by the institutional investor as choosing criteria for the targeted company.

- $\quad$ GDP = It reflects the growth rate of the real GDP (Real Gross Domestic Product) of the country in which the institutional funds conducted their operations. This variable takes the value 1 if has been used by the institutional investor as choosing criteria for the targeted company.

- $\quad$ Inflation = It reflects the mean inflation rate of the country where the institutional funds were operating in 2012-2013. This variable takes the value 1 if has been used by the institutional investor as a choosing criteria for the targeted company.

The figures used for this research were collected from annual report, investment relations, Bloomberg, Thomson Reuters, Bankscope and Eurostat. Moreover, the dataset has been enriched by data resulting from 7,845 interviews (70,11\% response rate) conducted, via CATI system, in 2013 to banks and insurance managers, in order to get information concerning their investing strategies. The sample of 5,500 institutional funds is progressively split into smaller and smaller partitions with increasing internal homogeneity in terms of the dependent variable. Using the CART (Classification And Regression Tree) each segmentation (called node) is characterized by a high level of homogeneity because of the application of Gini index. In this study the minimum rate of Gini Index is 0.0001 .

A terminal node is described as "pure" when the value of the dependent variable is the same for $100 \%$ of the cases in the node. In other words, based on the CART procedure, the database was split into ever more Yhomogeneous subsets (Campanella, 2014).

CART is widely held to be particularly suited to empirical studies (Olshen et al., 1984; Campanella, 2014; Del Giudice et al., 2016; Campanella et al., 2016; Campanella et al., 2016; Brida et al. 2009; Brida et al. 2010) for many reasons. First of all, it offers the chance of using both qualitative and quantitative dependent variables; second, the data set can be split using combinations of quantitative and qualitative variables as predictors and the splitting criterion itself is defined by minimizing the impurity level of a node. Finally, the algorithm can be used to prune large-size trees down to optimal dimensions (Razi \& Athappilly, 2005).

According to these characteristics, this method is particularly suitable for our purposes because of the presence of qualitative and quantitative variables.

Lastly, CART method allows the possibility to conduct robustness tests splitting the dataset in training sample $(60 \%)$ and test sample $(40 \%)$.

The overall efficiency of the proposed model was evaluated by the Receiver Operating Characteristic Curve (ROC Curve).

\section{Results and Discussion}

The model specifications and the results of our analysis are given in Table 1. The section on 'Specifications' provides information on the criteria for building the tree model, including the analysed variables, whereas the values reported in the section on 'Results' gives the number of aggregate nodes, the number of terminal nodes and the tree depth. 
Table 1. Model summary

\begin{tabular}{|c|c|c|}
\hline \multirow[t]{7}{*}{ Specifications } & Growing Method & CRT \\
\hline & Dependeat Variable & Bank_Insurabce \\
\hline & Independent Variables & $\begin{array}{l}\text { Size, NFP_Asset, Infiation, P_E, } \\
\text { Abnormal return, GDP, EBIT_Financial, } \\
\text { P_Casb, P_BV, Industry, EPS, ROE, } \\
\text { Current_natio, D_E }\end{array}$ \\
\hline & Valsdation & Split Sample \\
\hline & Maximum Trce Depth & 5 \\
\hline & $\begin{array}{l}\text { Minimum Cases in Pareat } \\
\text { Node }\end{array}$ & 100 \\
\hline & $\begin{array}{l}\text { Minimum Cases in Cbild } \\
\text { Node }\end{array}$ & 50 \\
\hline \multirow[t]{4}{*}{ Results } & $\begin{array}{l}\text { Independent Variables } \\
\text { Included }\end{array}$ & $\begin{array}{l}\text { Abnormal_retum, NFP_Asset, P_E, } \\
\text { Current_ratio, D_E, Industry, ROE, Inflation, } \\
\text { EPS, Size, EBIT_Financial, GDP, P_Cash, } \\
\text { P_BV }\end{array}$ \\
\hline & Number of Nodes: & 21 \\
\hline & $\begin{array}{l}\text { Number of Terminal } \\
\text { Nodes }\end{array}$ & 11 \\
\hline & Depth & 5 \\
\hline
\end{tabular}

We initially identified fifteen independent variables. All variables were included in the model. Figure 1 shows the tree diagram of the training sample at the end of the pruning process. The optimal sub-tree is shown in Figure 3. The 'Abnormal return' variable splits the data into two nodes, node 1 and node 2 . Data show that node 1 has a composition of $76.8 \%$ of Banks and $23.2 \%$ of Insurance (this means that $77.6 \%$ of banks have a positive abnormal return and $21.4 \%$ of insurance have a positive abnormal return), while node 2 displays a composition of $79.4 \%$ of Insurance and $20.6 \%$ of banks (this means that $22.4 \%$ of banks have a negative abnormal return and $78.6 \%$ of insurance have a negative abnormal return).

The subsequent best classification variable for funds in node 1 is leverage (node 3 ). Data show that node 3 has a composition of $85.8 \%$ of Banks and $14.2 \%$ of Insurance (this means that $83.8 \%$ of banks and $46.0 \%$ of insurance, which achieved a positive abnormal return, choose an higher leverage).

Another best classification variable is ROE (node 7). Data show that node 7 has a composition of $92.4 \%$ of Banks and $7.6 \%$ of Insurance (this means that $90.0 \%$ of banks and $45.0 \%$ of insurance, which achieved a positive abnormal return and a high leverage, choose an higher ROE).

Finally, funds with lower abnormal return than other funds are classified in node 2 . The subsequent best classification variable of node 2 is node 6 , which has the following composition: $87.4 \%$ insurance and $12.6 \%$ banks. This means that $85.2 \%$ of the insurance and $47 \%$ of the banks with negative abnormal return doesn't use the return of equity as a discriminatory variable. 


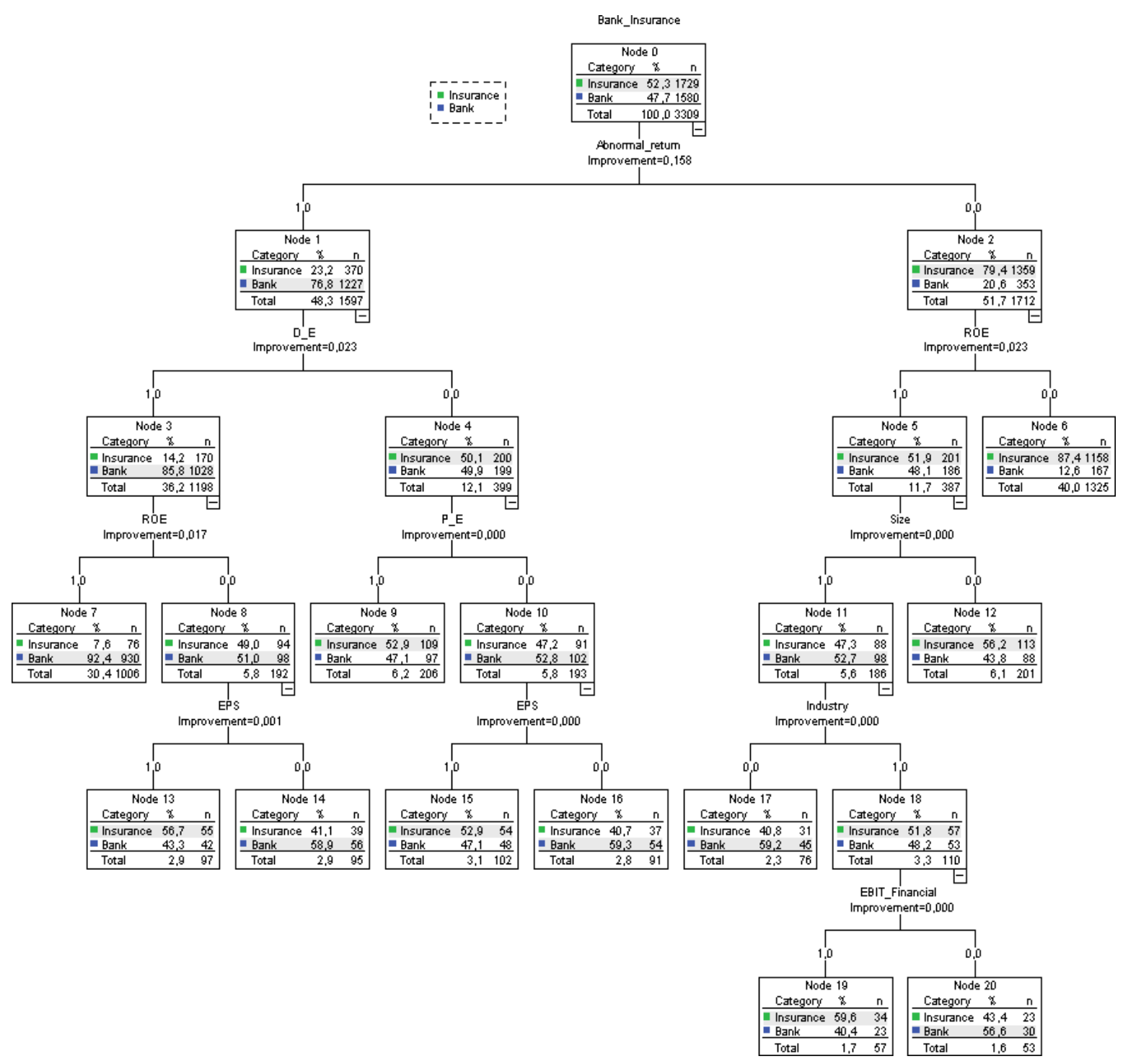

Figure 3. Training sample 


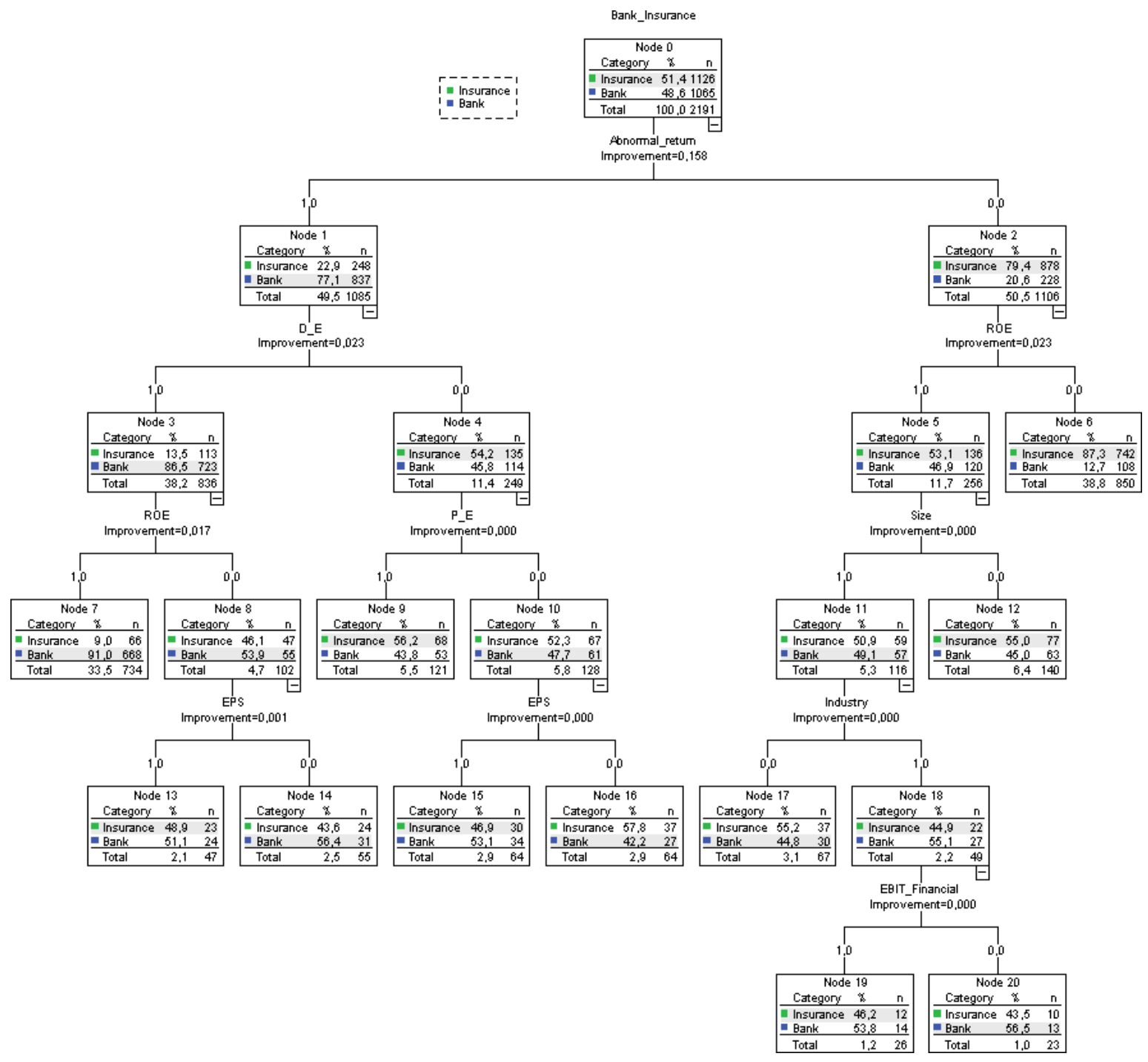

Figure 4. Test sample

The Risk and Classification Tables (Tabs 2 and 3) show that the classification error risk rate of the model is $20.3 \%$ with a 0.007 standard error value and that the correct classification rate obtained for the training sample is $79.7 \%$.

Table 2. Risk

\begin{tabular}{lcc}
\hline Sample & Estimate & Std. Error \\
\hline Training & 0.203 & 0.007 \\
Test & 0.215 & 0.009 \\
\hline
\end{tabular}

Growing Method: CRT - Dependent Variable: Bank_Insurance

Table 3. Classification

\begin{tabular}{|ll|c|c|c|}
\hline \multirow{2}{*}{ Sample } & Observed & \multicolumn{3}{|c|}{ Predicted } \\
\cline { 3 - 5 } & Insurance & Bank & Percent Correct \\
\hline Training & Insurance & 1523 & 206 & $88.1 \%$ \\
& Bank & 465 & 1115 & $70.6 \%$ \\
& Overall Percentage & $60.1 \%$ & $39.9 \%$ & $79.7 \%$ \\
\hline Test & Insurance & 952 & 174 & $84.5 \%$ \\
& Bank & 296 & 769 & $72.2 \%$ \\
& Overall Percentage & $57.0 \%$ & $43.0 \%$ & $78.5 \%$ \\
\hline
\end{tabular}

Table 4 summarizes the gain for nodes and shows the number of nodes, the number of cases, the average profit and ROI (Return on Investment). Node 7 performs best, node 6 worst. 
Table 5 refers to the target variable "Bank" and it includes the gain in percentage, the response rate and the percentage index (lift) per node.

Figures 3 and 4 illustrate their relative node performance compared to the gain and the index. In Figure 3, the gain chart increases rapidly towards $100 \%$ then falls along the diagonal. This graph indicates that the model is quite reliable. It can be seen that a model that does not provide information follows the baseline of the diagonal.

In Figure 5, the cumulative indexes plots tend to start above $100 \%$ and gradually decrease until they reach $100 \%$. This graph shows that the model is reliable. Indeed, in a reliable model, the value of the index starts well above $100 \%$, and then rapidly drops to $100 \%$. For a model that does not provide information, the line will overlap the $100 \%$ line for the whole chart.

Table 4. Gain Summary for Nodes

\begin{tabular}{|c|c|c|c|c|c|}
\hline Sample & Sode & $\mathrm{N}$ & Percent & Profit & 201 \\
\hline \multirow[t]{11}{*}{ Training } & 7 & 1006 & $30,4 \%$ & $4,47 \pi$ & $5,0 \%$ \\
\hline & 16 & 91 & $2,5 \%$ & 2,194 & $35 \%$ \\
\hline & 17 & 76 & $2,3 \%$ & 2,145 & $3,5 \%$ \\
\hline & 14 & 95 & 2,96 & 2,126 & $3,5 \%$ \\
\hline & 20 & 53 & 1,05 & 1,962 & $3,3 \%$ \\
\hline & 9 & 206 & $6,2 \%$ & 1,296 & $25 \%$ \\
\hline & is & 102 & $3,1 \%$ & 1,294 & $25 \%$ \\
\hline & 12 & 201 & $6.1 \%$ & 1.065 & $2,2 \%$ \\
\hline & 13 & 97 & $2,9 \%$ & 1,031 & $2,2 \%$ \\
\hline & 19 & 57 & $1,7 \%$ & .025 & $1.8 \%$ \\
\hline & 6 & 1325 & $40, n=$ & $-1,118$ & $-50 \%$ \\
\hline \multirow[t]{11}{*}{ Test } & 7 & 734 & 3335 & 4,391 & $5 \mathrm{~m}$ \\
\hline & 16 & 64 & $2,5 \mathrm{~s}$ &, 953 & $200 \%$ \\
\hline & 17 & 67. & $3,1 \%$ & 1,134 & $2,3 \%$ \\
\hline & 14 & 55 & $2.5 \%$ & 1,945 & $3,3 \%$ \\
\hline & 20 & 23 & 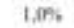 & 1,057 & 3,346 \\
\hline & 9 & 121 & $5,5 \%$ & 1,066 & $2,2 \mathrm{~N}$ \\
\hline & 15 & BA & 2.956 & 1,719 & $3,1 \%$ \\
\hline & 12 & 140 & 6,456 & L.190 & $2.3 \%$ \\
\hline & 13 & 47 & $2,1 \%$ & 1,574 & $2.9 \%$ \\
\hline & 19 & 26 & 1.25 & 1,709 & $3,1 \%$ \\
\hline & 6 & $\$ 50$ & $38 . \mathrm{K}:$ & $-1,111$ & $-4.5 \%$ \\
\hline
\end{tabular}

Growing Method: CRT - Dependent Variable: Bank_Insurance

Table 5. Target category: Bank - Gain for Nodes

\begin{tabular}{|c|c|c|c|c|c|c|c|}
\hline \multirow[b]{2}{*}{5 ample } & \multirow[b]{2}{*}{ Node } & \multicolumn{2}{|c|}{ Node } & \multicolumn{2}{|c|}{ Gain } & \multirow[b]{2}{*}{ Response } & \multirow[b]{2}{*}{ Index } \\
\hline & & $N$ & Percem & $\mathrm{N}$ & Percent & & \\
\hline \multirow[t]{11}{*}{ Inting } & Y & $\operatorname{Ton}$ & 70,5 & की & 915,5 & 020 & किस्म \\
\hline & ut & 91 & $2 \times 66$ & 4 & Ww & sa,h & Das: \\
\hline & 17 & $x_{0}$ & 235 & 45 & $2 \pi$ & 425 & เa4m: \\
\hline & H & 65. & 2in. & 86 & 3.54 & ss.m & $123,5 \%$ \\
\hline & 20 & 35: & ies & 90 & ins & $500 \mathrm{~h}$ & ines \\
\hline & - & 306 & $a=2 \times$ & on & $6.1 \%$ & की, 1 s & $\alpha m$ \\
\hline & 15 & let: & 214 & $\Rightarrow$ & sur: & 4,15 & $\operatorname{ans}$ \\
\hline & 17 & 209 & a.s & $x$ & 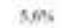 & $4 \times x$ & $91, \pi 6$ \\
\hline & D & $n$ & $2 n$ & $\$ 2$ & $2 \pi$ & 4335 & 9075 \\
\hline & is & 37. & $1+\pi$ & 23 & $1.5 \%$ & $A 1, A$ & ses.s. \\
\hline & i & 1928 & then: & its & $\tan 6$ & 120 & $2 x+5$ \\
\hline \multirow[t]{11}{*}{ fex } & 7 & 74 & $335 \%$ & काe & $2, \%$ & प्राग्र & किस, \\
\hline & is & is & $20 \%$ & 27 & $29 \%$ & $42 \pi$ & wonts \\
\hline & 19 & B? & $2,1 \%$ & $\infty$ & $2 \times \mathrm{Na}$ & $44 \mathrm{~m}$ & s.1n \\
\hline & is & ss & $25 s$ & $s t$ & $20 \mathrm{ni}$ & wh. & bur. \\
\hline & $3 \%$ & 25 & $\tan$ & 13 & $1=$ & 80 & $16,5 \%$ \\
\hline & 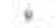 & 121 & $\$ 4$ & 53 & Sir: & $43 x$ & $00.1 \%$ \\
\hline & 15 & he & 205 & 34 & $22=6$ & $53,1 \%$ & 1003 \\
\hline & 12 & 140 & $a, w$ & 61 & $\sin 4$ & tosin. & yem \\
\hline & b & 6 & 215 & 24 & 205 & 31.18 & ins. $n$. \\
\hline & 19 & $2 \mathrm{~b}$ & 1.186 & 14 & 1.356 & $53 \% \mathrm{~K}$ & new: \\
\hline & 6 & 296 & $3 \times 5$ & us & ais & $12, \pi$ & 26.14 \\
\hline
\end{tabular}

Growing Method:CRT - Dependent Variable: Bank_Insurance 


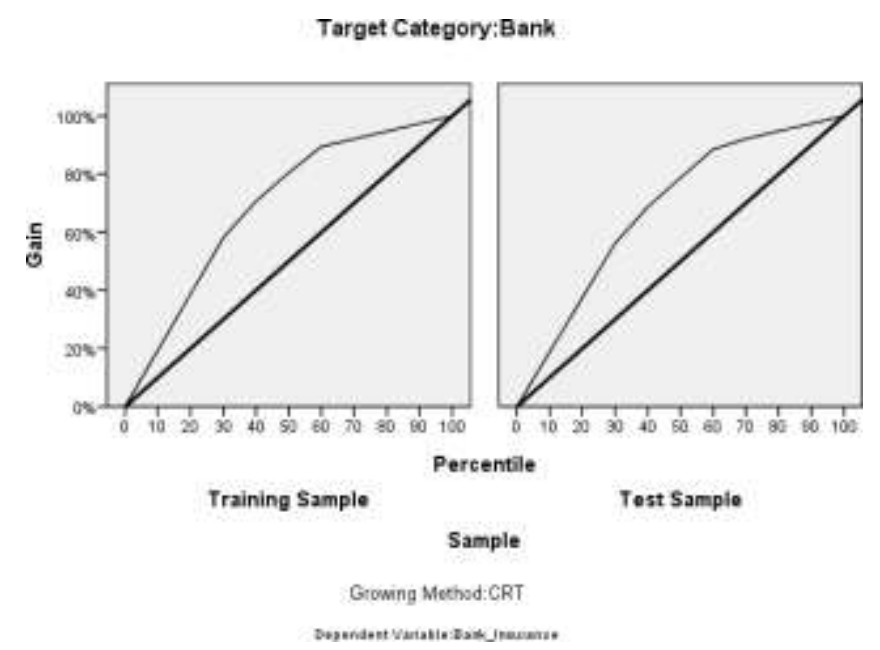

Figure 5. Target category: Bank - Node performance: gain

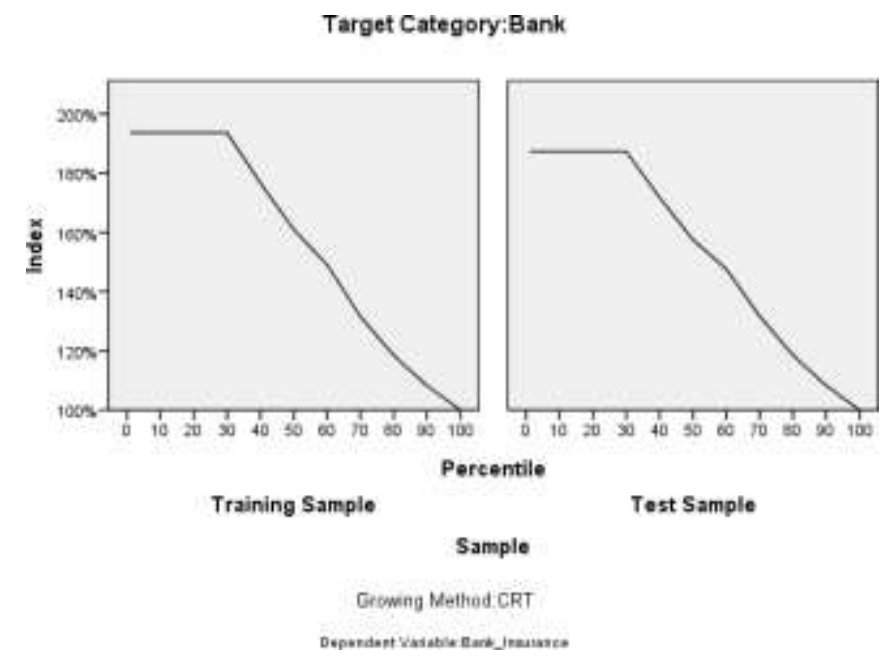

Figure 6. Target category: Bank - Node performance: index

The overall efficiency of the optimal tree was evaluated through the Receiver Operating Characteristic Curve using the predicted probability of the model (Table 6, Table 7 and Figure 7).

Table 6. Case Processing Summary

\begin{tabular}{|l|c|}
\hline ROI & Valid N (listwise) \\
\hline Positive & 2645 \\
Negative & 2855 \\
\hline
\end{tabular}

Notes: Larger values of the test result variable(s) indicate a stronger evidence for a positive actual state; (a.) the positive actual state is Bank.

The Area Under the Curve (AUC) in Figure 5 is equal to 0.863 . The best cut off is at 0.5185

(Youden's index $=0.579$ ) (Table 7 and Table 8 ). 


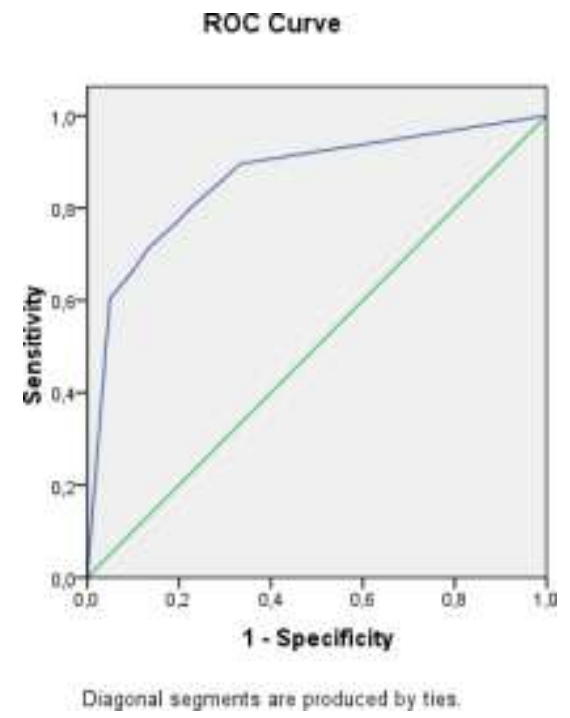

Figure 7. ROC Curve

Table 7. Area Under the Curve (AUC)

\begin{tabular}{|c|c|c|c|c|}
\hline & & & \multicolumn{2}{|c|}{ Asymptotic 95\% Confidence } \\
Interval
\end{tabular}

Notes: Predicted Probability for Bank_Insurance=1 has at least one link between the positive actual state group and the negative actual state group. Statistics may be biased; (a.) Under the nonparametric assumption; (b.) Null hypothesis: true area $=0.5$

Table 8. Coordinates of the curve

\begin{tabular}{|c|c|c|}
\hline $\begin{array}{c}\text { Positive if } \\
\text { Greater Than } \\
\text { or Equal To }\end{array}$ & Sensitivity & 1 - Specificity \\
\hline, 0000 & 1,000 & 1,000 \\
, 2648 &, 896 &, 335 \\
, 4182 &, 882 &, 318 \\
.4354 &, 857 &, 291 \\
, 4542 &, 800 &, 225 \\
, 4707 &, 769 &, 195 \\
, 5185 &, 712 &, 133 \\
.5778 &, 696 &, 122 \\
, 5908 &, 663 &, 099 \\
5928 &, 635 &, 076 \\
.7589 &, 604 &, 050 \\
1,0000 &, 000 &, 000 \\
\hline
\end{tabular}

Notes: Predicted Probability for Bank_Insurance=1 has at least one link between the positive actual state group and the negative actual state group; (a.) The smallest cut-off value is the minimum observed test value minus 1 , and the largest cut-off value is the maximum observed test value plus 1 . All the other cut-off values are the averages of two consecutive observed test values.

The study show that institutional investors that operate under a specific mandate (Bank) achieve higher abnormal returns, therefore Hypothesis $\mathrm{H} 1$ is confirmed.

Moreover the model show that institutional investors classified as "bank" uses data given by the fundamental analysis in choosing their stocks. The level of financial leverage and the return on equity seem to be the main parameters used by the best performer in choosing their portfolios. This may lead us to confirm Hypothesis $\mathrm{H} 2$. 


\section{Conclusion}

The objective of the article was to verify whether institutional investors with a specific mandate to invest realize or not superior performance compared to those who do not have a specific mandate and if this outcome is the result of the use of fundamental analysis for the selection of their portfolios. Since both hypotheses are confirmed, it seems appropriate to proceed with further specifications about the results achieved, also in the light of the theoretical framework described in the previous section of the article.

First it is appropriate to analyse portfolios that achieved returns higher than expected. It is confirmed that institutional investors operating under a specific mandate to invest, in most cases, gain superior performance. This may be attributable to the use of fundamental analysis in guiding their investment decisions. More in detail it was found that the use of some specific variable is able to better discriminate portfolios which have performed better than others.

The research shows that two variables have been decisive in discriminating the performance of institutional investors who have better performed: roe and financial leverage.

When an institutional investor selects a target company characterized by a high degree of financial leverage, this may result in exposing the investor to a higher level of risk: the financial risk. This is consistent with the second proposition of the Modigliani-Miller theorem concerning the financial structure. It is clear that the actual return is not necessarily consistent with what was expected at the time of investment and neither with what has been achieved in the past by the targeted company. However, it was found that the return on equity was the second variable that discriminates investments characterized by abnormal returns from the others.

This suggests that institutional investors with a higher risk propensity, in their portfolio selection, evaluate the consistency between the higher financial risks the returns that the targeted company has been able to achieve in the past. Selecting securities with a high level of leverage and high return on equity is a symptom of the willingness of the institutional investor to evaluate the target company's ability to successfully use financial leverage. In other words is the indicator of the ability of the firm to catch the increasing in the return on equity that follows a high degree of leverage when there are positive differentials between the operating income returns and the cost of borrowed funds.

This confirms what was suggested in the theoretical framework that led us to the formulation of research hypotheses. Institutional investors operating under a specific mandate to invest, not being subject to additional monitoring costs, have superior financial resources to use for fundamental analysis. In addition, using such a tool, they prefer to expose themselves to higher risk-return trade off with the aim of achieving higher returns. On the contrary, institutional investors that operate in the absence of a specific mandate to invest, realize, in most cases, lower returns compared to those expected. These kind of institutional investors mostly don't use fundamental analysis in selecting their target companies, because they can't sustain both the cost of fundamental analysis and the bonding costs related to the financial debt. Moreover, the cash flow expected by the Insurance Companies are lower, as a result of a lower risk- return trade off preferred by this type of investor in order to ensure the sustainability of debt and the corporate survival.

In conclusion, it is necessary to highlight the contribution of this research to the existing literature and its limitations. First of all, the research highlights the importance of having distinguished institutional investors according to the mandate received by savers. This classification, compared to previous research, allows to assess the implications of the mandate on the performance achieved in terms of abnormal returns. Secondly, this research allows us to examine the fundamental analysis role in determining the abnormal returns. With regard to this second point it has revealed that the financial leverage effect has an important role in discriminating investment, which achieved higher abnormal returns. Further research strengths are the theoretical framework associated with the contractual requirements that discriminate institutional investors depending on their relationship with the savers and an original methodology.

Obviously this article has limitations that could be overcome through further study, for example with a longitudinal analysis over a longer period of time, or taking into account the territorial peculiarities of investment funds or the ones of the target companies.

\section{References}

Alchian, A. A. (1965). The basis of some recent advances in the theory of management of the firm. The Journal of Industrial Economics, 30-41. https://doi.org/10.2307/2097649

Alchian, A. A., \& Demsetz, H. (1972). Production, information costs, and economic organization. The American economic review, 62(5), 777-795. 
Alchian, A. A., \& Kessel, R. A. (1962). Competition, monopoly and the pursuit of money. Aspects of labor economics, 14, 157-183.

Almazan, A., \& Suarez, J. (2003). Entrenchment and severance pay in optimal governance structures. The Journal of Finance, 58(2), 519-548. https://doi.org/10.1111/1540-6261.00536

Almazan, A., Brown, K. C., Carlson, M., \& Chapman, D. A. (2004). Why constrain your mutual fund manager?. Journal of Financial Economics, 73(2), 289-321. https://doi.org/10.1016/j.jfineco.2003.05.007

Andone, I., \& Sireteanu, N. A. (2009). A combination of two classification techniques for businesses bankruptcy prediction. Available at SSRN: https://ssrn.com/abstract=1527726 or https://doi.org/10.2139/ssrn.1527726

Brida, J. G., Gómez, D. M. \& Risso, W. A. (2009). Symbolic hierarchical analysis in currency markets: An application to contagion in currency crises. Expert Systems with Applications, 36(4), 7721-7728. https://doi.org/10.1016/j.eswa.2008.09.038

Brida, J. G., Pulina, M., Ria-o, E. M. M., \& Zapata-Aguirre, S. (2010). A Classification and Regression Tree (CART) to Analyse Cruisers' Expenditure Pattern and Perception in a Port of Call. Available at SSRN: https://ssrn.com/abstract=1666225 or https:// doi.org/10.2139/ssrn.1666225

Campanella, F. (2014). Assess the Rating of SMEs by using Classification And Regression Trees (CART) with Qualitative Variables. Review of Economics \& Finance, 4, 16-32.

Campanella, F., Del Giudice, M., \& Della Peruta, M. R. (2013). The role of information in the credit relationship. Journal of Innovation and Entrepreneurship, 2(1), 1-16. https://doi.org/10.1186/2192-5372-2-17

Campanella, F., Del Giudice, M., Thrassou, A., \& Vrontis, D. (2016). Ambidextrous organizations in the banking sector: an empirical verification of banks' performance and conceptual development. The International Journal of Human Resource Management, 1-31.

Campanella, F., Della, P. M. R., Bresciani, S., \& Dezi, L. (2016). Quadruple Helix and firms' performance: an empirical verification in Europe. The Journal of Technology Transfer, first-on-line, 1-18. https://doi.org/10.1007/s10961-016-9500-9

Campanella, F., Mustilli, M., \& D'Angelo, E. (2016). Efficient Market Hypothesis and Fundamental Analysis: An Empirical Test in the European Securities Market. Review of Economics \& Finance, 6, 27-42.

Coase, R. H. (1960). The problem of social cost. Journal of law and economics, 3(1). https://doi.org/10.1086/466560

Del Giudice, M., Campanella, F., \& Dezi, L. (2016). The bank of things: An empirical investigation on the profitability of the financial services of the future. Business Process Management Journal, 22(2), 324-340 https://doi.org/10.1108/BPMJ-10-2015-0139

Del Guercio, D., \& Hawkins, J. (1999). The motivation and impact of pension fund activism. Journal of financialeconomics, 52(3), 293-340. https://doi.org/10.1016/S0304-405X(99)00011-2

Demsetz, H. (1967, May). American Economic Review. In Papers and Proceedings of the Seventy- ninth Annual Meeting of the American Economic Association (Vol. 57, No. 2, pp. 347-359).

Gillan, S. L., \& Starks, L. T. (2000). Corporate governance proposals and shareholder activism: The role of institutional investors. Journal of financial Economics, 57(2), 275-305. https://doi.org/10.1016/S0304-405X(00)00058-1

Hart, O., \& Holmstrom, B. (2016). Contract Theory. The Sveriges Riksbank Prize in Economic Sciences in Memory of Alfred Nobel 2016, 1-47

Jensen, M. C., \& Meckling, W. H. (1976). Theory of the firm: Managerial behavior, agency costs and ownership structure. Journal of financial economics, 3(4), 305-360. https://doi.org/10.1016/0304-405X(76)90026-X

Kahn, C., \& Winton, A. (1998). Ownership structure, speculation, and shareholder intervention. The Journal of Finance, 53(1), 99-129. https://doi.org/10.1111/0022-1082.45483

Kaplan, S. N., \& Minton, B. A. (1994). Appointments of outsiders to Japanese boards: Determinants and implications for managers. Journal of Financial Economics, 36(2), 225-258. https://doi.org/10.1016/0304-405X(94)90025-6

McManus, J. C. (1975). The costs of alternative economic organizations. Canadian Journal of Economics, 334-350. https://doi.org/10.2307/134237 
Monsen Jr, R. J., \& Downs, A. (1965). A theory of large managerial firms. Journal of Political Economy, 73(3), 221-236. https://doi.org/10.1086/259012

Olshen, R., Breiman, L., Friedman, J. H., \& Stone, C. J. (1984). Classification and Regression Trees. Wadsworth International Group.

Razi, M. A., \& Athappilly, K. (2005). A comparative predictive analysis of neural networks (NNs), nonlinear regression and classification and regression tree (CART) models. Expert Systems with Applications, 29(1), 65-74. https://doi.org/10.1016/j.eswa.2005.01.006

Silver, M., \& Auster, R. (1969). Entrepreneurship, profit, and limits on firm size. The Journal of Business, 42 (3), 277-281. https://doi.org/10.1086/295195

\section{Copyrights}

Copyright for this article is retained by the author(s), with first publication rights granted to the journal.

This is an open-access article distributed under the terms and conditions of the Creative Commons Attribution license (http://creativecommons.org/licenses/by/4.0/). 